\title{
Information Problems of Anthropologists
}

This paper discusses the background of the information problems of anthropologists, the character of their discipline, and the consequences of this character for the arrangement and cataloging of anthropology literature in the library. An exploration is made of the seriousness of two aspects of a present information crisis: (1) access, both retrospective and current; and (2) awareness. An analysis of current indexing is included. Partial and possible aids to alleviate the problem are enumerated. A questionnaire sent to professional anthropologists to determine their information-seeking habits, problems, and needs is described. The conclusion lists four major needs of anthropologists which should be met.

\begin{abstract}
A
NTHROPOLOGISTs are currently having more difficulty with information problems than are the members of many other major academic disciplines. There was a time when the scholar in this field, as in most, could keep up fairly well with his specialty. He had read most or all of its literature-perhaps even owned much of it personally-and he was able to read all pertinent material as it was published. This has now been impossible, however, for many years. The problems caused by a new superabundance of material are compounded by lack of manpower, specialization, and a tendency for the literature to deteriorate in quality. Consequently the anthropologist finds his perseverance and detective skill exercised almost as much in the library as in the field, and his collecting instinct as much for his information needs as for his museum.
\end{abstract}

Diana Amsden is a Catalog Librarian and a doctoral candidate in anthropology at the University of New Mexico.
The nature of anthropology itself explains part of the problem; as the "science of man" it is concerned with humankind in the dimensions of time and space, on every part of the globe-even under water and into space-and from the genesis of man into the future. Because of this scope it has been proposed that anthropology will become what the classics were: the foundation and the framework of a good education. This universal quality is revealed in the observation that the anthropologist considers few subjects "outside his field"; i.e., he believes most human knowledge to be within the legitimate range of his interests.

Its Classification. Anthropology is classified academically as a social science; yet, as Kroeber says, its father was natural history and its mother aesthetically-inclined humanities. ${ }^{1}$ Because of the breadth, depth, and comprehensiveness of its interests, it is a master science, a

1 Alfred L. Kroeber, "The History of the Personality of Anthopology," American Anthropologist, LXI (June 1959), 398-404. 
member of the physical sciences and the humanities as much as of the social sciences. This is demonstrated dramatically in any university library, whatever its classification system; material of use to the anthropologist is scattered literally from one end of the system to the other.

As any experienced library researcher can testify, the subject headings for anthropology in the average university card catalog leave at least as much to be desired as the classification, whether the Sears List of Subject Headings, used with the Dewey classification, or the Library of Congress subject headings are used. Enough descriptors are usually not assigned to a given work; the descriptors are often not sufficiently specific for the topic; and perhaps worst, the subject headings frequently do not appear to be organized into a pattern designed to include all pertinent material in a logical system. Even when a list of subject headings is available for consultation, location of material is difficult. This is not always the case, of course, in special libraries with special subject heading systems, such as that used by the Peabody museum library at Harvard University.

Often important books are shelved in a separate reference room, sometimes even hidden behind the reference desk where the patron may not see them, or even suspect their existence. Government documents may also be shelved separately and not listed in the card catalog, but classified according to their own system. Different libraries, of course, differ in their decisions whether to list periodicals and other serials in the card cata$\log$, or in distinguishing between serials and monographic series, the latter often requiring cataloging of individual issues. Anthropologists, as patrons in most fields, are probably not aware that it is standard library practice to omit such beginning phrases of titles as "Introduction to ..." and "Principles of ..." on the title cards. These differing characteristics and inconsistencies, despite the good reasons for their existence, frustrate and handicap even the experienced library researcher.

\section{SERIOUSNESS OF THE INFORMation Problem}

The seriousness and costliness of the information problem of scholars are demonstrated by figures from the fields of natural science and technology, which have invested enormous sums in elaborate equipment for information storage and retrieval. It has been estimated that it is less expensive to repeat research costing $\$ 100,000$ than it is to search the literature to discover whether it has already been done. ${ }^{2}$ The information explosion of the last two decades has made bibliographic control in anthropology, already poor, almost impossible, despite the efforts to date of anthropological societies, institutions, federal agencies, and international organizations.

The two major problems anthropologists face in obtaining information are: (1) difficulty of access; and (2) difficulty of maintaining awareness.

Access. For access we find few good sources in anthropology comparable to the best in some other disciplines.

Retrospective access. The Harvard University Peabody Museum of Archaeology and Ethnology Author and Subject Catalogues, one of G. K. Hall and Company's growing number of special library catalogs, is anoutstanding exception. The Harvard University Peabody museum library began in the 1860 's to collect what is perhaps "the most comprehensive and balanced collection of ethnological, archaeological, and physical anthropological material in the world," containing more than eighty thousand items at the time of G. K.

\footnotetext{
2 Joseph N. Bell, "Crisis: How Can We Store Human Knowledge?" Popular Mechanics, CXVIII (Nov. 1962), 104-10, 224.
} 
Hall's publication of the catalog (1963), and eighty-seven thousand according to a later count. ${ }^{3}$ The library has a geographically arranged classification scheme, and includes all the anthropological journals and the proceedings and reports of anthropological societies and museums throughout the world. Most important, it has incorporated into its catalog the equivalent of a periodical index. The questionnaire results described later in this paper, however, indicate that only 29 per cent of the respondents made any real use of this fine resource.

An unusual body of research material developed by anthropologists is the $\mathrm{Hu}$ man Relations Area Files, started at Yale in 1937, used by the United States government during World War II in the Pacific theatre, and incorporated as a research organization in 1949 with aid from the Social Sciences Research Council and the Carnegie Corporation. Donald Morrison reported a project to computerize it in FORTRAN II language at Northwestern University. ${ }^{4} \mathrm{~A}$ microfilm edition is available also.

Current access. Anthropology has no current general index or abstract service, and this is perhaps the most desperate need outside of funds for purchasing additional literature. The anthropologist cannot do what the biologist, for ex-

\footnotetext{
${ }^{3}$ Margaret Currier, librarian of the Harvard University Peabody Museum of Archaeology and Ethnology. Personal communication.

"Donald Morrison, "Indexing the Human Relations Area Files," American Behavioral Scientist, VII (June $1964), 49-50$.
}

ample, often can: go to one source (Biological Abstracts) for all pertinent previous data. Indexes cover few anthropology periodicals, and the number of periodicals is increasing.

Analysis of Indexing. Table 1 shows not only the deplorable situation, but also the fact that it is worsening rapidly. When this research on information needs of anthropologists was begun, the tenth edition (1963) of Ulrich's Directory of Periodicals was current. The eleventh edition (1966) and its first supplement are compared with the tenth edition.

This table is based entirely on Ulrich's listings under the categories of "Anthropology" and "Archaeology." The data in the 1966 column includes the five additional journals listed in the first supplement.

The eleven fields to which the user of Ulrich's 1963 edition is referred are: classical studies, education, folklore, geography, history, Orientalia, sociology, literature and philology, biology, art galleries and museums. The seventeen fields in the 1966 edition include, in addition to most of the foregoing: political science, Indians, religion and theology, sound recording reproduction, zoology, natural and physical sciences, general bibliography, art, literary periodicals and political reviews, and general periodicals -Italy. The wider range of fields reflects the increasing interrelatedness of anthropology with other academic disciplines.

The 1963 edition lists fourteen indexing sources, which are, with the number

TABLE 1

\begin{tabular}{|c|c|c|c|}
\hline & 1963 & 1966 & $\begin{array}{l}\text { Per Cent } \\
\text { Increase }\end{array}$ \\
\hline $\begin{array}{l}\text { Total anthropology and archaeology journals } \\
\text { Number of other fields listed which have journals pertinent }\end{array}$ & 208 & 264 & 27 \\
\hline to anthropology & 11 & 17 & 55 \\
\hline Number of indexes including these journals & 14 & 24 & 71 \\
\hline Number of indexings of these journals & 30 & 39 & 13 \\
\hline Maximum number of times single journal indexed & 4 & 11 & 175 \\
\hline
\end{tabular}


of anthropology journals indexed: Art Index (6), Social Sciences and Humanities Index (formerly International Index) (4), Psychological Abstracts (2), Catholic Periodicals Index (1), Biological Abstracts (14), British Humanities Index (6), Chemical Abstracts (8), Public Affairs Information Service (PAIS) (1), Index to Religious Periodical Literature (1), Canadian Periodical Index (1), Engineering Index (1), Index Medicus (2), Nutrition Abstracts and Reviews (1), and Sociological Abstracts (1), a total of forty-four indexings of thirty periodicals in fourteen indexes.

The 1966 edition lists twenty-four indexes, including most of the foregoing. The corresponding figures are: Art Index (6), Social Sciences and Humanities Index (8), Psychological Abstracts (4), Catholic Periodicals Index (1), Biological Abstracts (14), British Humanities Index (6), Chemical Abstracts (8), PAIS (1), Index to Religious Periodical Literature (1), Canadian Periodical Index (1), Engineering Index (2), Index Medicus (5), Nutrition Abstracts and Reviews (3), Religious and Theological Abstracts (1), Biological and Agricultural Index (1), Music Index (1), Reader's Guide to Periodical Literature (3), Metallurgical Abstracts (2), Meteorological and Geoastrophysical Abstracts (2), Science Abstracts (2), Australian PAIS (1), Abridged Reader's Guide (1), Mathematical Reviews (1), and Applied Science and Technology Index (1), making a total of seventy-six indexings of thirty-nine periodicals in twenty-four indexes. It is obvious that the indexing of anthropology periodicals done at present is for the benefit of other interested disciplines, and not of anthropologists. Table 15 gives further data on the indexing of anthropology periodicals.

It does not come as a surprise to learn that anthropologists make little use of indexes. Appel and Gurr, ${ }^{5}$ in their study of the bibliographical needs of social and behavioral scientists including a number of anthropologists, discovered that relatively little use is made of special resources like indexes. They found that footnotes and journal bibliographies are more often used than abstracts or personal service from librarians. They also felt that there was some ignorance of good available resources, e.g., 89 per cent of their respondents were unaware of the UNESCO bibliographies. Table 15 , reporting use of indexes by respondents to the questionnaire administered by the author of this paper, indicates the same situation: the Art Index is used by 2.6 per cent, Biological Abstracts by 10.5 per cent, Social Sciences and Humanities Index by 5.3 per cent, Psychological Abstracts by 9.2 per cent, British Humanities Index by 1.3 per cent, and Chemical Abstracts by 0 per cent.

Ulrich's gives circulation figures for some of the journals. The circulation range of indexed journals in the categories of "Anthropology" and "Archaeology" in the 1963 edition was five hundred to thirty-two hundred. In the 1966 edition the range was seven hundred and twenty to ten thousand. The comparable figures for non-indexed journals was up to twenty-eight thousand in the 1963 edition and to 19,120 in the 1966 edition. The particular journals covered are not identical in the two editions. Even acknowledging that a high circulation figure is not necessarily evidence of quality, it appears that not all the most valued journals are being indexed.

\section{Awareness}

The problem of maintaining awareness, like that of access, can be demonstrated by figures from the bibliographically favored fields of engineering and technology. It is estimated that the physical impossibility of keeping current in one's field, resulting in wasteful dupli5 John S. Appel and Ted Gurr, "Bibliographic Needs
of Social and Behavioral Scientists," American Behavof Social and Behavioral Scientists," Am
ioral Scientist, VII (June 1964) 51-54. 
cation of research, is costing up to 50 per cent of our current multi-billion-dollar effort in research and development, and that wasteful duplication and mountainous literature searches consume as much as 70 per cent of our scientists' time. $^{6}$

\section{Current Partial and Possible Aids}

Current Anthropology and American Anthropologist are used by most anthropologists to maintain awareness.

Automatic Subject Citation Alert (ASCA), a new current awareness service designed by the Institute for Scientific Information, utilizes user-prepared profiles consisting of questions or subject citations for specific works reflecting the user's current interests. Each week he receives a report showing which current source journal article cites them. Some anthropologists are now using ASCA. ${ }^{7}$ The services of the National Referral Center are useful to some anthropologists also.

Vincent Davis proposes a Centralized Bibliography Bank for the behavioral sciences, characterized by comprehensiveness, with access to University Microfilms and all other organizations that record, index, and copy unpublished materials. ${ }^{8} \mathrm{He}$ is seconded by many anthropologists. It might be proposed that for anthropology, the center for such a MEDLARS-type service should be the best library collection in anthropology available, in an institution with an active and progressive interest in the field. Support could be sought from this parent institution, the federal government, professional societies, and foundations interested in anthropology. Abroad, we

\footnotetext{
- Allen Kent, Specialized Information Centers (Washington, D.C.: Spartan Books, 1965), 5-6.

${ }^{7}$ Professor Omer Stewart, Department of Anthropology, University of Colorado. Personal communication.

8 Vincent Davis, "A Proposed Bibliography Bank for the Behavioral Sciences," American Behavioral Scientist, VII (June 1964), 67-70.
}

can expect the Maison des Sciences de l'Homme to be a major documentation center in the social sciences.

One device which could prove promising is Kochen's Adaptive Man-Machine Nonarithmetic Information Processing (AMNIP), which includes a growing thesaurus, built by the users themselves in the course of using the man-machine system. ${ }^{9}$ Continuous updating is inherent in the system, in which users train the memory by entering statements in a semi-formalized language through a keyboard console. The user inserts query words; the console responds with the number of items, e.g., documents, abstracts, associated with those words. The user can then expand or limit his query, the machine assisting on demand by displaying words with which to expand or limit his query. This man-machine conversation can be repeated up to the exhaustion of the machine's vocabulary of associations and/or the user's need. Then the user can enter his own word associations where he found the machine's store of associations inadequate. It is a sort of living index.

Another system, briefly noted in the literature, is Syntagmatic Organization Language (SYNTOL), ${ }^{10}$ an all-embracing system for use on materials which have already been organized by some other system, developed in France by Gardin in 1960-62 and used at the Centre d'Analyse Documentaire pour l'Afrique Noire in cultural anthropology. The informative abstracts are ten to fifteen lines long. The language is compiled empirically on the literature and assumed needs. Terms are entered into the system in natural language, but the indexer must be skilled in building and revising the vocabulary.

Translation service like that offered

\footnotetext{
${ }^{\circ}$ Manfred Kochen, Some Problems in Information Science (New York: Scarecrow Press, 1965).

${ }^{10}$ Jean-Claude Gardin, "A European Research Program in Document Retrieval," American Behavioral Scientist, VII (June 1964), 12-16.
} 
science and technology by the Special Libraries Association translations center at the John Crerar library is needed badly in anthropology. Transliteration at least of literature printed in the Cyrillic alphabet would be helpful to those accustomed to only the Roman alphabet, and would be less expensive than actual translation. The Harvard University Peabody Museum of Archaeology and Ethnology began a Russian translation series in 1959.

There are several current awareness techniques adaptable to anthropology. The "Current Contents" idea in the sciences should be used. Citation indexing, already in wide use in the natural sciences, is particularly adapted to use in the social sciences and humanities. The Science Citation Index is an ordered list of references (cited works) in which each reference is followed by a list of the sources (citing works) which cite it. In other words, it is simply a streamlining of a favorite research technique of anthropologists. With a citation index one can go backward or forward to build a bibliography. ${ }^{11,12}$

A new current awareness aid is Discovery-or Dissemination-of Information Through Co-operative Organization (DICO), an automatic information dissemination system. ${ }^{13}$ One variant is Stochastic Adaptive Sequential Information Dissemination System (SASIDS), an adaptive network for dissemination that adjusts automatically to take account of feedback from recipients. Documents are automatically distributed; each participant reports which of them he finds relevant and interesting, omitting obviously standard publications, and

11 Eugene Garfield, "Citation Indexes in Sociological and Historical Research," American Documentation, XIV (October 1963), 289-91.

12 Eugene Garfield, "Citation Indexing: A Natural Science Literature Retrieval System for the Social Sciences," American Behavioral Scientist, VII (June 1964), 58-61.

${ }^{13}$ Ibid. then the system distributes abstracts of that document to all other members. This system is being tested at the Space Sciences Laboratory of the University of California at Berkeley, and should be adaptable to anthropology.

\section{The Questionnaire and Its Results}

In spite of this serious information problem in anthropology, a review of both anthropology and library literature reveals almost no work done on the subject, with the possible exception of John Howland Rowe's work. ${ }^{14,15}$ In order to ascertain the information gathering habits of anthropologists, as well as to determine the specific problems, the author prepared a questionnaire.

Questionnaires were sent to 250 persons selected at random from the December 1965 "Associates in Current Anthropology" in Current Anthropology. To date there have been ninety-two responses, of which seventy-six were usable for tabulation of data.

Characteristics of the Respondents and Implications. Table 2 shows that the largest number of respondents have $\mathrm{PhD}$ degrees. Also, most were trained in the United States. From this it can be seen that most of the respondents are professional anthropologists of some standing, and that consequently the questionnaire results presumably reflect the needs of the professional anthropologist more faithfully than those of the anthropology

\footnotetext{
14 John H. Rowe, "Library Problems in the Teaching of Anthropology," in David G. Mandelbaum, et al, Resources for the Teaching of Anthropology, (Berkeley: University of California Press, 1963).

${ }^{15} \mathrm{John}$ H. Rowe, "La Organizacion de Bibliotecas Antropologicas," Boletin Bibliografico, Año XX, XVIII (1947), 157-78.
}

TABLE 2

Degrees and Where Earned

\begin{tabular}{|c|c|c|}
\hline & |United States & Foreign \\
\hline $\begin{array}{l}\text { PhD } \\
\text { Master } \\
\text { Bachelor } \\
\text { Other. }\end{array}$ & $\begin{array}{r}47 \\
1 \\
2 \\
0\end{array}$ & $\begin{array}{r}15 \\
4 \\
2 \\
2\end{array}$ \\
\hline
\end{tabular}


TABLE 3

Decade Degree Was Earned

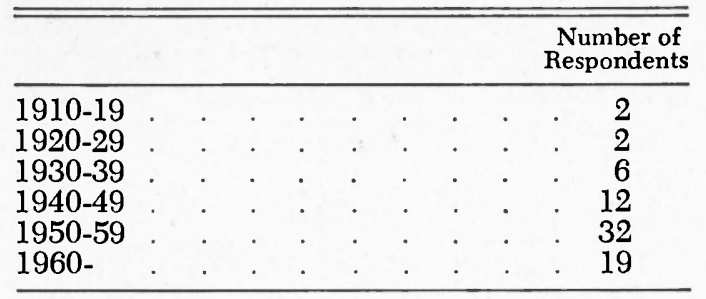

student, except insofar as these needs may be similar. Also, it can be fairly assumed that the respondents are disproportionately of English or American background, and that consequently the needs of the English-speaking anthropologist are reflected more accurately than those of the non-English-speaking one.

According to Table 3, thirty-two of the respondents were trained in the decade 1950-1959, and fifty-one were trained between 1950 and the present. This may indicate that the respondent group is disproportionately young compared with the generality of professional anthropologists. On the other hand, this may have special value in that the needs

TABLE 4

Where EMPLOYed

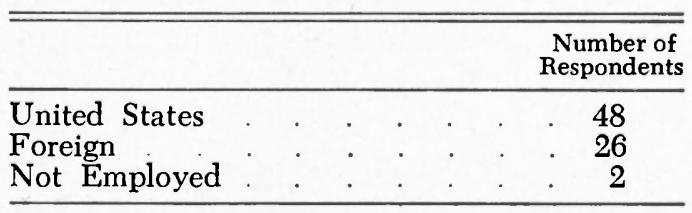

expressed by these younger respondents may indicate the needs of contemporary anthropology students also.

The places of employment shown in Table 4 corresponds roughly with the places degrees were earned shown in Table 1. Although some foreign-trained respondents are employed in the United States and vice versa, Table 4 does not reveal any "brain drain" problem such as that which concerns some other disciplines which have a tendency for a disproportionate number of foreigntrained professional persons to seek United States employment.

Table 5 shows the nature of the employing institution. The total number of institutions exceeds the number of respondents due to the fact that several institutions fell in more than one category. Universities are the commonest employing institution, followed by mu-

TABLE 5

TyPe OF Institution

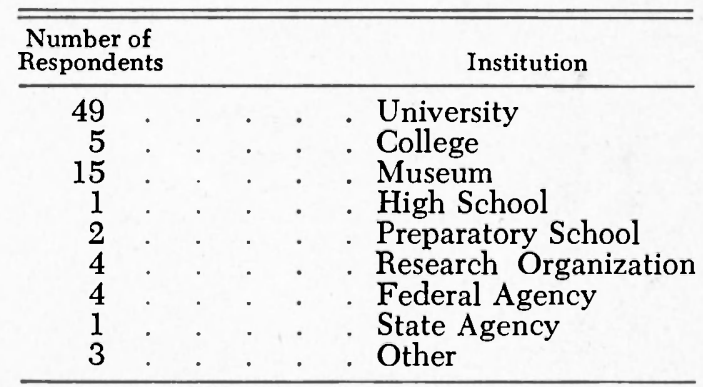

TABLE 6

Most Time-Consuming Activities

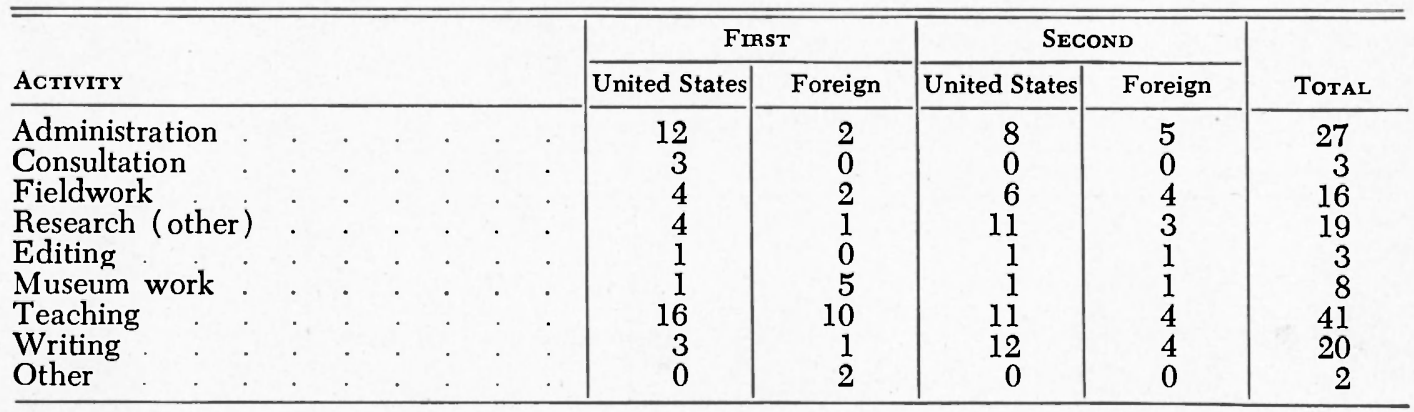


TABLE 7

Area of Specialization

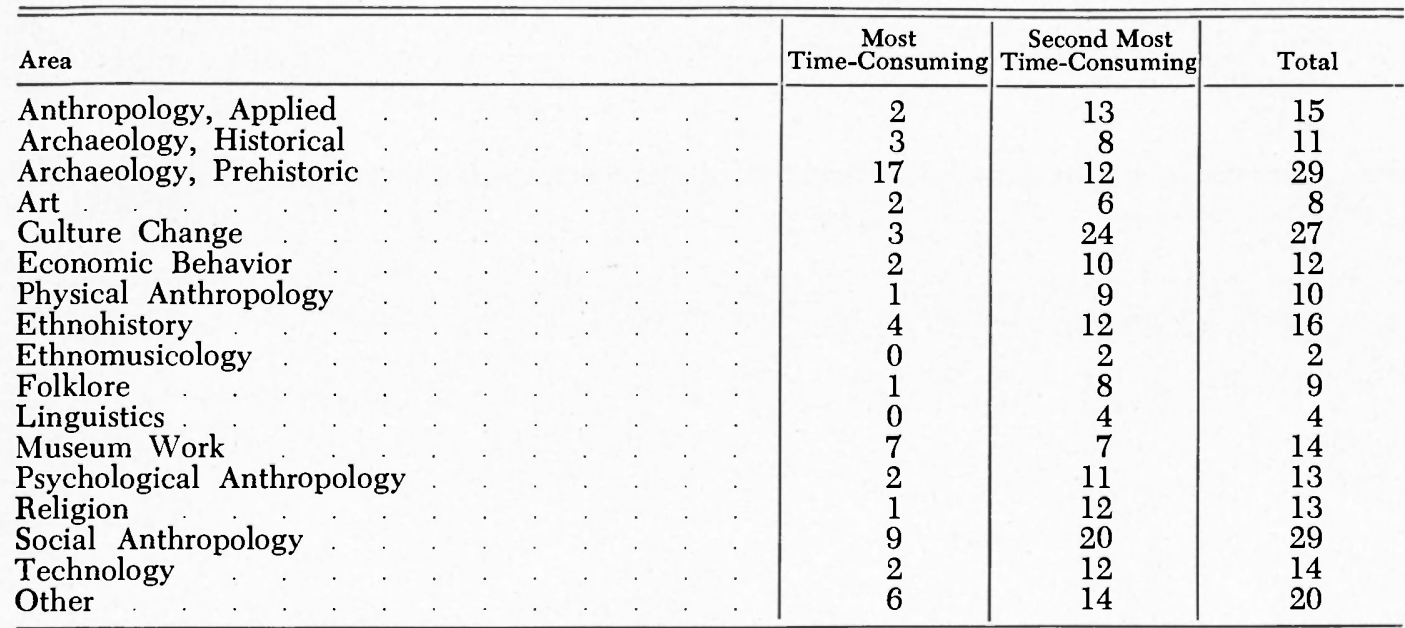

seums. Consequently, university and museum needs should be revealed most accurately in the following data.

Table 6 shows the first- and secondmost-time-consuming professional activities of the respondents. Teaching is far in the lead, mentioned first or second by forty-six respondents, followed by administration, writing, non-fieldwork research, fieldwork, and museum work.

Table 7 shows the areas of specialization of the respondents, and it appears that their interests are fairly well distributed over the range of subdisciplines. Consequently, the needs of these respondents should be somewhat representative of the needs of anthropologists in general.
Table 8, showing the number of publications produced by the respondents in the last five years, reveals a very productive group in contributing to the overwhelming body of literature that is the main concern of this paper. The seventy-six respondents produced 1,339 items ranging from books to book reviews, an average of eighteen items apiece.

Table 9 bears out the observation that anthropology is related to the humanities and the sciences as much as to the social sciences. The most pertinent areas outside the field searched for information are history, geography, biology, psychology, geology, zoology, and economics.

TABLE 8

Publications in Last 5 Years

\begin{tabular}{|c|c|c|c|c|c|c|c|c|}
\hline \multirow[b]{2}{*}{ ITEM } & \multicolumn{7}{|c|}{ Number of Respondents } & \multirow[b]{2}{*}{ TotaL } \\
\hline & $1-5$ & $6-10$ & $11-15$ & $16-20$ & $21-25$ & $26-30$ & $31-60$ & \\
\hline \multirow{6}{*}{$\begin{array}{l}\text { Books } \\
\text { Articles } \\
\text { Conference } \\
\text { Papers } \\
\text { Book Reviews } \\
\text { Other } \\
\text { Total }\end{array}$} & 35 & 2 & 0 & 0 & 0 & 9 & 0 & 74 \\
\hline & 28 & 22 & 5 & 5 & 2 & 3 & 2 & 563 \\
\hline & 36 & 8 & 2 & 1 & 1 & 1 & 0 & 266 \\
\hline & 5 & 1 & 0 & 0 & 1 & 0 & 2 & 144 \\
\hline & 55 & 15 & 1 & 0 & 0 & 0 & 0 & 292 \\
\hline & & & & & & & & 1339 \\
\hline
\end{tabular}


TABLE 9

Pertinent Areas Outside Anthropology

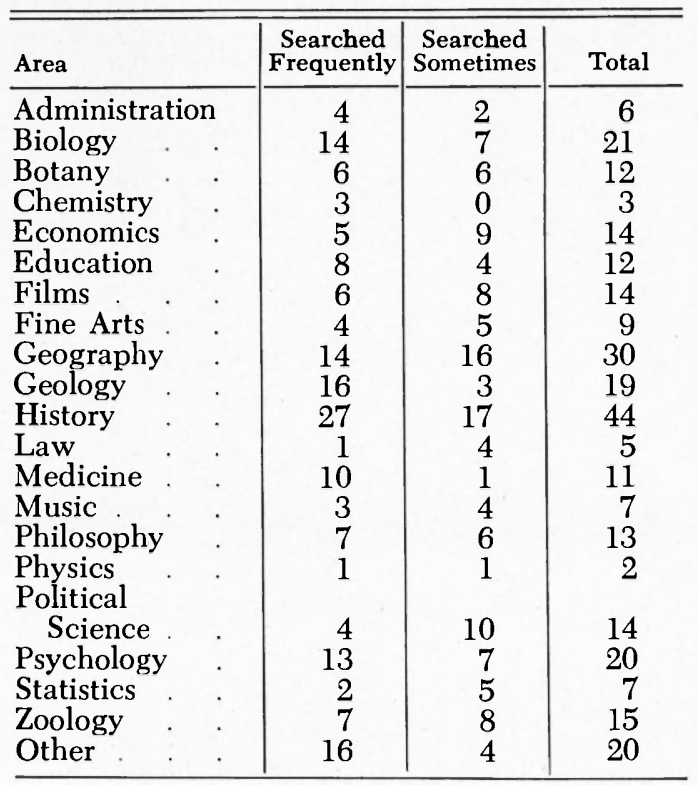

TABLE 10

Foreign Languages Read

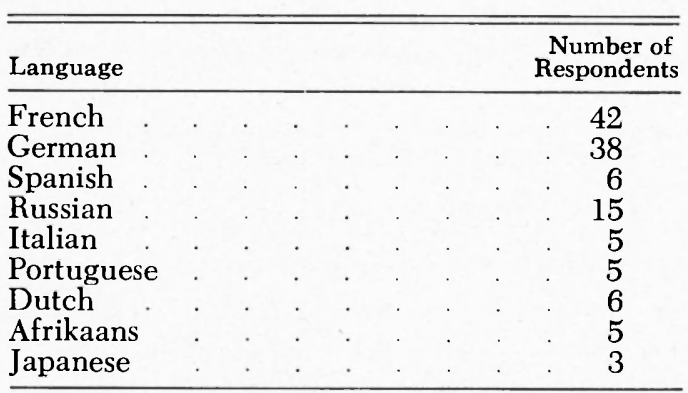

Table 10 indicates the number of respondents reading each of the major languages in which anthropological literature is published. Numerous additional languages were mentioned, as could be expected, the average respondent reading two and more often three foreign languages, and several reading ten or more. It was interesting to note that Afrikaans is read by as many respondents as Italian or Portuguese. Due to the small number of respondents, this figure should not be construed to mean that Afrikaans is read by as many anthro-
TABLE 11

Ways ANThropologists Get Information

\begin{tabular}{|c|c|c|c|}
\hline & \begin{tabular}{|c} 
Fre- \\
quently
\end{tabular} & $\begin{array}{l}\text { Some- } \\
\text { times }\end{array}$ & Total \\
\hline $\begin{array}{l}\text { Conversation with } \\
\text { other anthropologists }\end{array}$ & 35 & 26 & 61 \\
\hline $\begin{array}{l}\text { Conversation with } \\
\text { non-anthropologists }\end{array}$ & & & \\
\hline $\begin{array}{l}\text { non-anthropologists } \\
\text { Informal meetings }\end{array}$ & 24 & 22 & 46 \\
\hline $\begin{array}{l}\text { 1nformal meetings } \\
\text { with colleagues }\end{array}$ & 25 & 27 & 52 \\
\hline $\begin{array}{l}\text { Conferences and other } \\
\text { formal meetings }\end{array}$ & 19 & 25 & 44 \\
\hline Visitors & 10 & 23 & 33 \\
\hline Correspondence & 16 & 32 & 48 \\
\hline Pre-publication copies & 3 & 16 & 19 \\
\hline $\begin{array}{c}\text { Anthropological } \\
\text { literature }\end{array}$ & 60 & 2 & 62 \\
\hline $\begin{array}{l}\text { Non-anthropological } \\
\text { literature }\end{array}$ & 25 & 17 & 42 \\
\hline Library card catalog & 15 & 18 & 33 \\
\hline Indexes and abstracts & 16 & 14 & 30 \\
\hline $\begin{array}{l}\text { Footnotes or } \\
\text { bibliographies in } \\
\text { books }\end{array}$ & 29 & 20 & 49 \\
\hline $\begin{array}{l}\text { Separate or mono- } \\
\text { graphic bibliographies }\end{array}$ & 18 & 23 & 41 \\
\hline $\begin{array}{l}\text { Book reviews or } \\
\text { publishers an- } \\
\text { ouncements }\end{array}$ & 26 & 28 & 54 \\
\hline Seminar presentations & 7 & 19 & 26 \\
\hline Other & 11 & 1 & 12 \\
\hline
\end{tabular}

pologists as Italian or Portuguese. However, the high figure for readers of Russian is no doubt indicative of the growing need for proficiency in Russian in order to utilize, for example, the monographic series of the Akademiia Nauk Institute of Ethnography and Institute of Archaeology.

Information-Gathering Habits of Respondents. Table 11 reveals the current favorite information sources of anthropologists. Anthropological literature and

TABLE 12

Hours Spent Per Week Getting Information

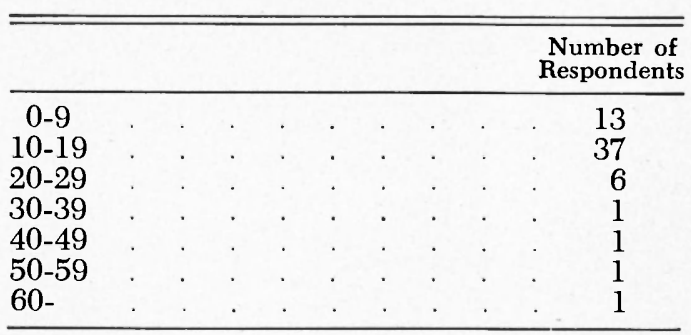


conversation with other anthropologists head the list, naturally enough, followed by book reviews or publishers' announcements, informal meetings with colleagues, footnotes or bibliographies in books, and correspondence. The lesser use of the library card catalog, indexes, and abstracts indicates a need for improvement of what should be more efficient keys to information.

Table 12 indicates that the typical respondent spends ten to nineteen hours a week getting information, the average being twelve hours, or the equivalent of one or two days a week. These seventysix respondents spend a total of approximately 890 hours a week getting information. It should be noted that in this field, work is frequently seasonal, summer being spent in the field and winter in such activities as teaching and writing.

Table 13, showing the age of periodicals used, suggests that the library practice sometimes found in shelving periodicals more than a few years old in a separate area, although perhaps the most efficient policy for some of the natural sciences, is not best for anthro-
TABLE 13

Age of Periodicals Used

\begin{tabular}{l|c|c|c}
\hline \hline & \multicolumn{2}{|c|}{$\begin{array}{c}\text { NUMBER oF } \\
\text { RESPONDENT }\end{array}$} & \\
\cline { 2 - 3 } AGE & Often & Sometimes & TotaL \\
\hline Less than one & & & \\
year old & 56 & 12 & 68 \\
1-5 years old. & 47 & 24 & 71 \\
5-10 years old & 28 & 34 & 62 \\
More than 10 & & & 64 \\
years old . & 24 & 30 & 64 \\
\hline
\end{tabular}

pology. Although the "very often" column indicates that periodicals are used slightly less as time passes, the "sometimes" column seems to indicate the reverse, so that when these columns are totaled, the value of anthropology periodicals is revealed to remain sufficiently stable to justify continuous shelving.

Table 14 shows the usefulness of types of anthropological literature. As could be expected, journals publishing papers based on original research and monographs are most used. Lack of accessibility seems to be a problem in obtaining foreign materials, masters theses, and other unpublished material, doctoral dissertations in particular.

TABLE 14

Forms of Literature Used

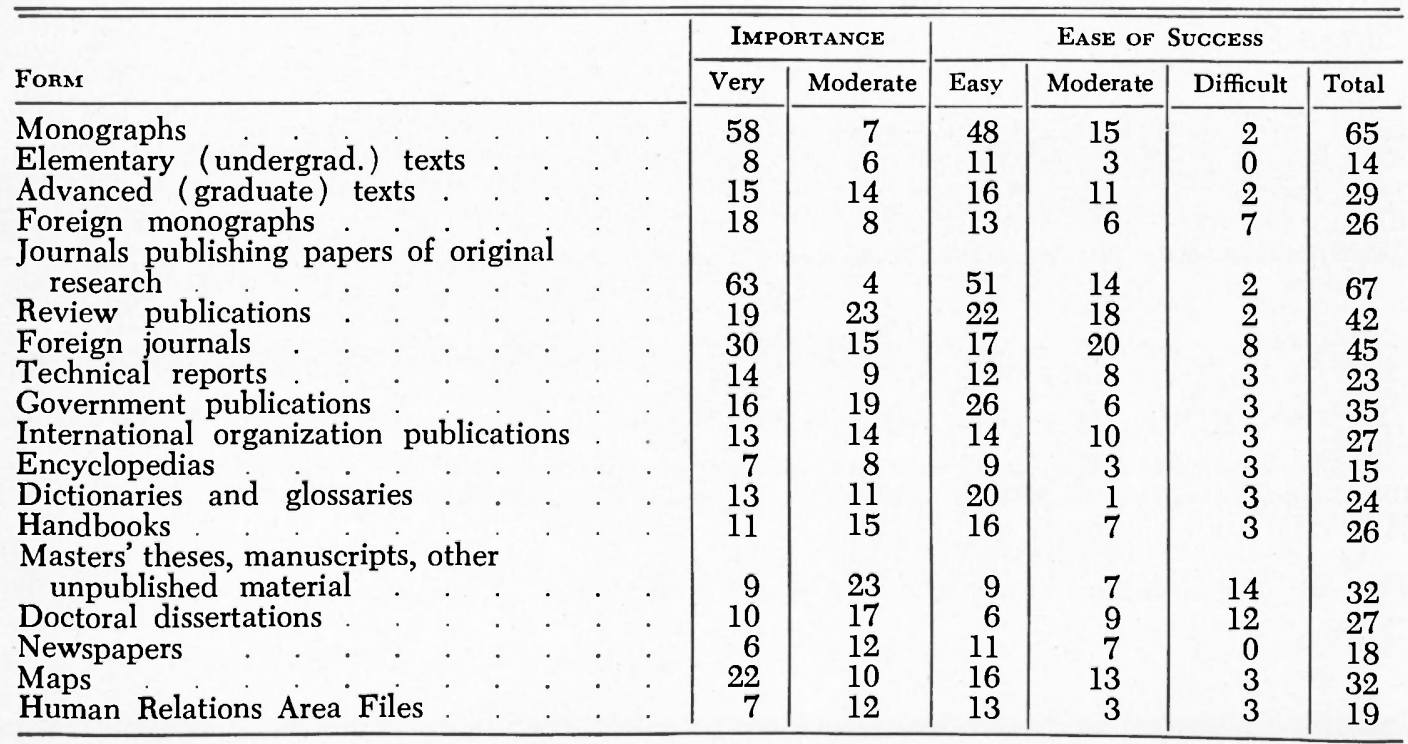


TABLE 15

USE OF LITERATURE

\begin{tabular}{|c|c|c|c|c|c|c|}
\hline Title & $\mathbf{R}$ & $\mathrm{o}$ & $\mathbf{P}$ & $\mathrm{L}$ & Circulation & Indexes \\
\hline Abstracts of New World Archaeology . & 15 & 2 & 16 & 1 & & \\
\hline Africa $(\mathrm{M})$ & 17 & 3 & 9 & 12 & 1900 & $\cdots$ \\
\hline African Abstracts & 7 & 3 & 2 & 8 & $750-800$ & $\ldots$ \\
\hline $\begin{array}{l}\text { American Anthropologist (M) Soc. Sci. } \\
\text { Hum. Ind., Psych. Abstr. }\end{array}$ & 50 & 13 & 47 & 16 & $\ldots$ & 2 \\
\hline $\begin{array}{l}\text { American Antiquity (M) Soc. Sci. Hum. } \\
\text { Ind. }\end{array}$ & 26 & 4 & 23 & 6 & 2200 & 1 \\
\hline $\begin{array}{l}\text { American Journal of Archaeology Chem. } \\
\text { Abstr., Soc. Sci. Hum. Ind. }\end{array}$ & 5 & 12 & 2 & 15 & $2600-2800$ & 2 \\
\hline $\begin{array}{l}\text { American Journal of Physical Anthropology } \\
\text { (M) Biol. Abstr. Chem. Abstr. Ind. }\end{array}$ & & & & & & \\
\hline $\begin{array}{l}\text { (M) Biol. Abstr., Chem. Abstr., Ind. } \\
\text { Med., Nutr. Abstr. }\end{array}$ & 10 & 7 & 8 & 8 & 1180 & 4 \\
\hline Anthropological Quarterly (M) Cath. Ind. & 6 & 13 & 2 & 15 & 720 & 1 \\
\hline $\begin{array}{l}\text { Anthropological Society of Japan Journal } \\
\text { L'Anthropologie (M) Biol. Abstr. }\end{array}$ & $\begin{array}{l}4 \\
5\end{array}$ & $\begin{array}{r}2 \\
14\end{array}$ & $\begin{array}{l}3 \\
1\end{array}$ & $\begin{array}{r}3 \\
20\end{array}$ & 800 & $i$ \\
\hline Anthropos (M) & 2 & 24 & 1 & 23 & 1000 & \\
\hline Antiquaries Journal Brit. Hum. Ind. & 4 & 1 & 3 & 4 & $\ldots$ & 1 \\
\hline Antiquity (M) Brit. Hum. Ind., Art Ind. : & 9 & 16 & 4 & 21 & $\ldots$ & 2 \\
\hline $\begin{array}{l}\text { Antropologie } \\
\text { Archaeology (M) Art Ind. } \cdot \cdot \cdot \cdot\end{array}$ & $\begin{array}{l}1 \\
8\end{array}$ & $\begin{array}{r}5 \\
16\end{array}$ & $\begin{array}{l}1 \\
1\end{array}$ & $\begin{array}{r}4 \\
25\end{array}$ & $9000-10,000$ & 1 \\
\hline Archives Suisse d'Anthropologie Generale & 0 & 0 & 0 & 1 & & $\ldots$ \\
\hline Art Index & 1 & 1 & 0 & 3 & 1412 & $\ldots$ \\
\hline Arts et Traditions Populaires & 1 & 1 & 1 & 2 & $\ldots$ & \\
\hline Artibus Asiae Art Ind. & $\begin{array}{l}0 \\
3\end{array}$ & $\begin{array}{l}2 \\
3\end{array}$ & $\frac{1}{3}$ & $\begin{array}{l}2 \\
3\end{array}$ & $\cdots$ & 1 \\
\hline $\begin{array}{l}\text { Annual Bibliography of Folklore } \\
\text { Biblical Archaeologist Art Ind., Bel. Per., }\end{array}$ & & & & & & \\
\hline Bel. \& Theol. Abstr. & 0 & $\underline{0}$ & 0 & 0 & $\cdots$ & 3 \\
\hline "Bibliographie Americaniste" & 1 & 5 & 0 & 7 & $\ldots$ & $\cdots$ \\
\hline "Bibliographie de l'Oceanie" & 4 & 3 & 1 & 5 & $\ldots$ & $\ldots$ \\
\hline Bibliographie Ethnographique de l'Afrique & 1 & 5 & 0 & 8 & & \\
\hline $\begin{array}{l}\text { Sud-Saharienne } \\
\text { "Bibliography of Canadian Anthropology" }\end{array}$ & 1 & $\begin{array}{l}3 \\
4\end{array}$ & 2 & $\stackrel{\circ}{3}$ & $\cdots$ & $\cdots$ \\
\hline Biennial Review of Anthropology . & 13 & 16 & 13 & 15 & $\cdots$ & \\
\hline Biological Abstracts Chem. Abstr. & 2 & 6 & 1 & 7 & $\ldots$ & 1 \\
\hline Boletín Bibliográfica de Antropología & 1 & 5 & 2 & 3 & 1500 & \\
\hline British Humanities Index $:$ & 0 & 1 & 0 & 2 & & $\ldots$ \\
\hline Buck: Introduction to Polynesian & 2 & $?$ & 2 & $?$ & & \\
\hline $\begin{array}{l}\text { Anthropology } \\
\text { Chemical Abstracts Biol. Abstr. }\end{array}$ & 0 & 0 & 0 & 1 & 6660 & 1 \\
\hline COWA Surveys and Bibliographies & 5 & 8 & 7 & $\overline{5}$ & $\cdots$ & $\cdots$ \\
\hline $\begin{array}{l}\text { Current Anthropology (M) Soc. Sci. Hum. } \\
\text { Ind. }\end{array}$ & 54 & 11 & 63 & 2 & & 1 \\
\hline Current Contents & 0 & 1 & 0 & $\overline{1}$ & & $\ldots$ \\
\hline Elkin: Social Anthropology in Melanesia & 1 & 3 & 2 & 4 & & $\ldots$ \\
\hline Ethnohistory (M) & 7 & 18 & 7 & 16 & 500 & $\because$ \\
\hline Ethnology Soc. Sci. Hum. Ind. . . . & 21 & 15 & 23 & 12 & $2500+$ & 1 \\
\hline $\begin{array}{l}\text { Ethnos (M) } \\
\text { Excerpta Medica Journals Biol Abstr. }\end{array}$ & & & & 12 & $\cdots$ & $\cdots$ \\
\hline Chem. Abstr., Ind. Med. & 4 & 2 & 2 & 4 & $\ldots$ & ... \\
\hline $\begin{array}{l}\text { I. Anatomy, Anthropology, Embryology, } \\
\text { Histology }\end{array}$ & 5 & 2 & 2 & 5 & $\ldots$ & \\
\hline XXIII. Human Genetics & 3 & 2 & 1 & 3 & $\ldots$ & $\ldots$ \\
\hline Folklore Brit. Hum. Ind. & 2 & 3 & 4 & 3 & $\ldots$ & $\ldots$ \\
\hline "Folklore Bibliography" (Southeastern & & & & & & \\
\hline $\begin{array}{c}\text { Folklore Quarterly) } \\
\text { Geographica Helvetica Biol. Abstr. }\end{array}$ & $\begin{array}{l}3 \\
0\end{array}$ & $\begin{array}{l}1 \\
0\end{array}$ & $\begin{array}{l}3 \\
0\end{array}$ & 1 & 1500 & 1 \\
\hline Harvard University Peabody Museum of & & & & & & \\
\hline Archaeology and Ethnology Catalogue & 13 & 9 & 1 & 19 & & \\
\hline Hesperia Art Ind. . . & 0 & 1 & 0 & 2 & 667 & 1 \\
\hline Homo Biol. Abstr. & 2 & 2 & 0 & 5 & 1000 & 1 \\
\hline $\begin{array}{l}\text { Human Biology (M) Biol. Abstr., Biol. \& } \\
\text { Agric. Ind. Chem. Abstr. Ind. Med., }\end{array}$ & & & & & & \\
\hline Nutr. Abstr., Psych. Abstr. & 6 & 9 & 5 & 10 & $\ldots$ & 6 \\
\hline
\end{tabular}


TABLE 15 (Cont.)

\begin{tabular}{|c|c|c|c|c|c|c|}
\hline Title & $\mathbf{R}$ & o & $\mathbf{P}$ & $\mathrm{L}$ & Circulation & Indexes \\
\hline $\begin{array}{l}\text { Human Organization (M) Soc. Sci. Hum. } \\
\text { Ind. }\end{array}$ & 11 & 15 & 13 & 14 & 2700 & 1 \\
\hline Human Relations Area Files & 5 & 12 & 0 & 17 & 2600 & 1 \\
\hline India. Department of Anthropology Index & 1 & 2 & 1 & 2 & & $\ldots$. \\
\hline $\begin{array}{l}\text { International Bibliography of Social and } \\
\text { Cultural Anthropology (UNESCO) (M) }\end{array}$ & & & & & & \\
\hline International Journal of American & 4 & 11 & 2 & 14 & & ... \\
\hline Linguistics (M) Soc. Sci. Hum. Ind. & 5 & 5 & 4 & 6 & 1200 & 1 \\
\hline Internationale Volkskundliche Bibliographie & 1 & 0 & 1 & 1 & & \\
\hline Israel Exploration Journal Chem. Abstr. & 0 & 2 & 0 & 2 & 1350 & 1 \\
\hline Israel Exploration Society Bulletin & 0 & 0 & 0 & 0 & 1750 & \\
\hline $\begin{array}{l}\text { Journal of African History Brit. Hum. Ind., } \\
\text { Soc. Sci. Hum. Ind. } \\
\text { Journal of American Folklore (M) Music }\end{array}$ & 8 & 3 & 3 & 9 & 1385 & 2 \\
\hline Ind., Soc. Sci. Hum. Ind. & 6 & 8 & 5 & 9 & & 2 \\
\hline Journal of East Asiatic Studies & 3 & 4 & 3 & 2 & 500 & \\
\hline Keesing. Culture Change & 3 & 4 & 4 & 5 & & \\
\hline Keesing: Social Anthropology in Polynesia & 2 & 4 & 1 & 6 & & \\
\hline Language (M) Psych. Abstr. & 3 & 4 & 3 & 5 & 4500 & 1 \\
\hline Man (M) Biol. Abstr., Brit. Hum. Ind. & 20 & 20 & 18 & 24 & 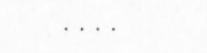 & 2 \\
\hline $\begin{array}{l}\text { Mandelbaum et al. "Resources for the } \\
\text { Teaching of Anthropology" }\end{array}$ & 5 & 17 & 19 & 5 & & \\
\hline Natural History (now incorporated with & & & & & & \\
\hline Nature, q.v.) Biol. Abstr., R. G. & 11 & 11 & 8 & 18 & 145,000 & 2 \\
\hline $\begin{array}{l}\text { Nature } \\
\text { Oceania (M) P.A.I.S. }\end{array}$ & $\begin{array}{l}5 \\
9\end{array}$ & $\begin{array}{l}12 \\
10\end{array}$ & $\begin{array}{l}1 \\
4\end{array}$ & $\begin{array}{l}18 \\
17\end{array}$ & 750 & 1 \\
\hline Palestine Exploration Quarterly Brit. Hum. & & & & & & \\
\hline $\begin{array}{l}\text { Ind. } \\
\text { Polynesian Society }(M)\end{array}$ & $\begin{array}{l}1 \\
9\end{array}$ & $\frac{0}{5}$ & $\begin{array}{l}0 \\
7\end{array}$ & $\begin{array}{l}2 \\
8\end{array}$ & 1300 & 1 \\
\hline Psychological Abstracts Biol. Abstr. & 2 & 5 & 1 & 8 & 7800 & 1 \\
\hline Revue Arqueologique Art Ind. & $\overline{1}$ & 0 & 0 & 1 & & 1 \\
\hline $\begin{array}{l}\text { Royal Anthropological Institute, London. } \\
\text { Index to Current Periodicals Received. }\end{array}$ & 6 & 7 & 6 & 7 & & \\
\hline Royal Anthropological Institute of Great & & & & & & \\
\hline $\begin{array}{l}\text { Britain and Ireland Journal (M) (now } \\
\text { merged with Man, q.v.) }\end{array}$ & 23 & 19 & 18 & 16 & & \\
\hline $\begin{array}{l}\text { Royal Society of Antiquaries in Ireland } \\
\text { Brit Hum. Ind. }\end{array}$ & 0 & 3 & 0 & 4 & 925 & 1 \\
\hline $\begin{array}{l}\text { Brit. Hum. Ind. } \\
\text { Royal Society of Canada. Transactions. Biol. }\end{array}$ & 0 & 3 & 0 & 4 & 925 & 1 \\
\hline $\begin{array}{l}\text { Abstr., Can. Ind., Chem. Abstr., Eng. } \\
\text { Ind., Met. Abstr. }\end{array}$ & 1 & 0 & 0 & 3 & & 5 \\
\hline $\begin{array}{l}\text { Science Biol. Abstr., Chem. Abstr., Eng. E. } \\
\text { Ind., Ind. Med., Met. Abs., Meteor. \& } \\
\text { Geoastro. Abstr., Nutr. Abstr., Psych. } \\
\text { Abstr., R. G. Sci. Abstr. }\end{array}$ & & & & & & \\
\hline $\begin{array}{l}\text { Abstr., R. G., Sci. Abstr. } \\
\text { Scientific American Ind. Med., Math. R., } \\
\text { Meteor. \& Geoastro. Abstr., Met. Abstr., } \\
\text { Psych. Abstr., R. G., Sci. Abstr., A. S. } \\
\text { \& T. Ind., Abr. R. G., Biol. Abstr., Chem. }\end{array}$ & 28 & 17 & 23 & 19 & $94,785(1963)$ & 10 \\
\hline $\begin{array}{l}\text { Abstr. } \\
\text { Siegel. Acculturation Abstracts }\end{array}$ & $\begin{array}{r}18 \\
1\end{array}$ & $\begin{array}{r}16 \\
4\end{array}$ & $\begin{array}{r}22 \\
2\end{array}$ & $\begin{array}{r}15 \\
3\end{array}$ & & 11 \\
\hline Sociological Abstracts & 5 & 8 & 4 & 10 & 2000 & \\
\hline Southwestern Journal of Anthropology (M) & & & & & & \\
\hline $\begin{array}{l}\text { Biol. Abstr., Psych. Abstr., Soc. Sci. } \\
\text { Hum. Ind. }\end{array}$ & & & & & & \\
\hline $\begin{array}{l}\text { Hum Ind. } \\
\text { Sudan Notes and Records }\end{array}$ & $\begin{array}{r}32 \\
4\end{array}$ & $\begin{array}{r}22 \\
2\end{array}$ & $\begin{array}{r}27 \\
0\end{array}$ & $\begin{array}{r}23 \\
6\end{array}$ & 1700 & 3 \\
\hline Vanyajati & 0 & 0 & 0 & 0 & 1000 & \\
\hline $\begin{array}{l}\text { Wiltshire Archaeology and Natural History } \\
\text { Magazine }\end{array}$ & & & & & & \\
\hline $\begin{array}{l}\text { Magazine } \\
\text { Zeitschrift für Ethnologie (M) }\end{array}$ & 0 & 0 & 0 & 0 & .... &. \\
\hline $\begin{array}{l}\text { Zeitschrift für Ethnologie (M) } \\
\text { Zeitschrift für Morphologie und }\end{array}$ & 1 & 9 & 1 & 9 & & \\
\hline Anthropologie Biol. Abstr. & 1 & 2 & 0 & 3 & $\ldots$ & 1 \\
\hline
\end{tabular}


TABLE 16

IMPORTANCE OF LiRRary SERvices

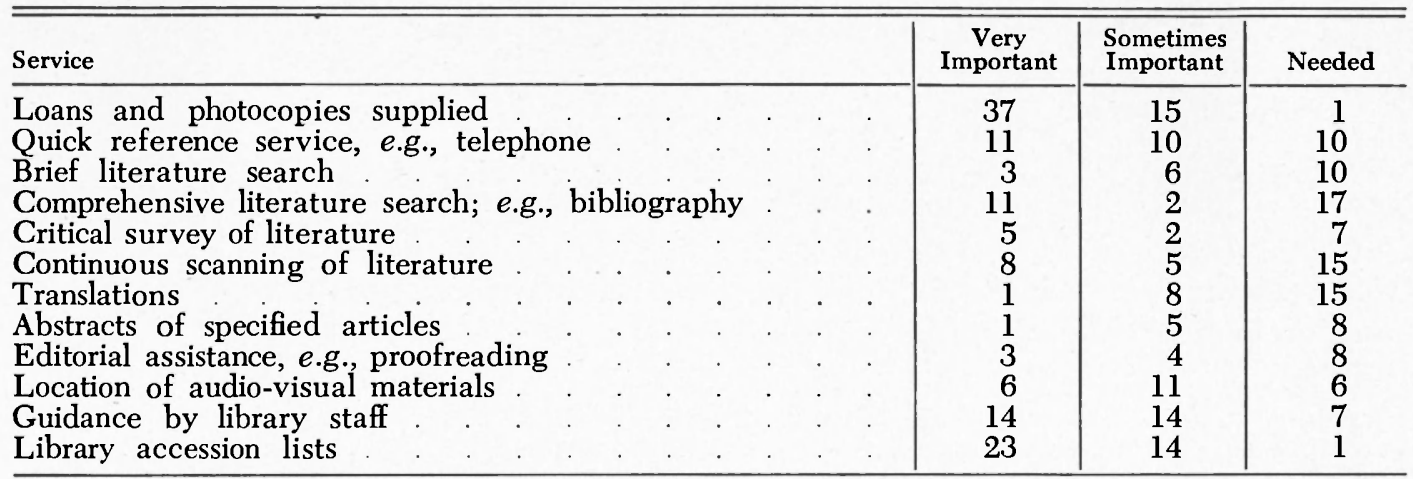

Table 15 consists of individual bibliographical resources selected from four sources: (1) indexed anthropology and archaeology journals from Ulrich's 1963 edition (current at the time the questionnaire was prepared), (2) Carl White's Sources of Information in the Social Sciences, 1963, (3) Rexford Beckham's "Resources for the Teaching of Anthropology" in David Mandelbaum et al.'s Resources for the Teaching of Anthropology (Berkeley: University of California Press, 1963), and several leading indexes. Each item includes the following information: ( $\mathrm{M}$ ) recommended by Beckham; $\mathrm{R}$ regularly used; $\mathrm{O}$ often used; P personal copy; L library copy. If Ulrich's 1966 edition gives a circulation figure, this is included. The number of indexings is given, and the indexes named after the title. The most used journals are Current Anthropology, American Anthropologist, Southwestern Journal of Anthropology, Science, Royal Anthropological Institute of Great Britain and Ireland Journal, Scientific American, and Man. The fifth and seventh of these have recently merged. Heavy reliance on library subscriptions is obvious, few respondents having the means to purchase all the literature they need. Dozens of additional periodicals were listed by respondents, the most notable perhaps being museum publications like Kiva, Masterkey, Plateau, Plains Archaeologist, El Palacio, etc. A comparison of usage figures and indexing figures will reveal poor correlation.

Needs and Problems of Respondents. Tables 16 and 17 should be of particular

TABLE 17

Problems in Gathering Information

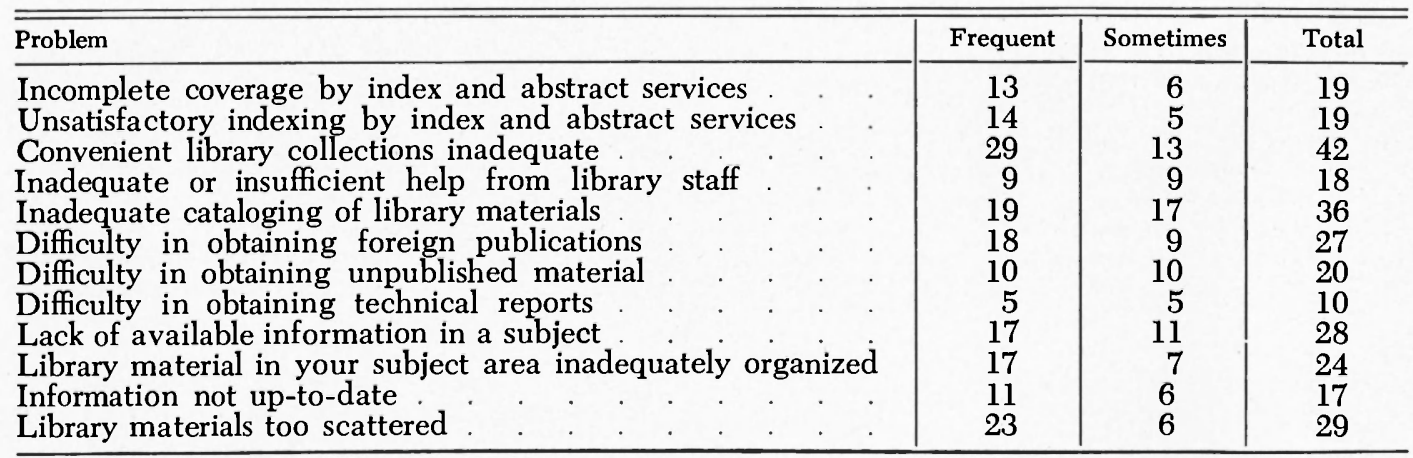


interest to librarians serving anthropologists. The most appreciated services now available are loans and photocopies, library accession lists, guidance by the library staff, quick reference service, bibliography compilation, and location of audio-visual materials. The services desired most are bibliography compilation, brief literature search, continuous literature scanning, translation, and abstracting. The first and second are of a highly individual nature, best carried out by a colleague or assistant, whereas the last two could be done most efficiently in some centralized manner. The need for continuous scanning reaffirms the need for a service like the aforementioned ASCA.

Table 17 explores problems encountered by anthropologists attempting to obtain information. Inadequacy of collections is the major complaint, whose only alleviating aspect may be that it is a good excuse for travel. Many respondents showed sympathy and with understanding of the library's effort to give good service with limited funds. The second problem, scattering of materials, was discussed earlier. It is not probable that this situation can be improved, for reasons which are to the credit of the discipline; it is so broad and deep that it cannot be confined to a single corner of the library. Inadequate cataloging of library materials is another major complaint, but it is likely that only in the specialized museum or departmental library can this problem be solved, for the university library usually has neither the subject-area-trained staff nor the money for this intensive cataloging. Simultaneously avoiding scattering of library materials and having thorough cataloging is rarely practical in university budgets. The obtaining of foreign publications should improve steadily, especially with cooperative international bibliographical ventures, such as the Library of Congress' overseas cataloging of foreign materials. Lack of available information in a subject can be due to absence of research or to difficulty of locating research results. This is one small aspect of the general problem of needing a good indexing service. The problem of inadequate organization of library materials in an anthropological subdiscipline can probably be solved only in the specialized anthropology library.

One respondent, Alfred E. Dittert of the Laboratory of Anthropology in Santa $\mathrm{Fe}$, believes a punched-card system with needles could be used to advantage in a specialized anthropology library. Also, he is concerned with the possibility of starting a Southwestern Anthropology Bibliographical Center to handle the plethora of unpublished material, including correspondence. Unpublished material is a major source of information needed by anthropologists. ${ }^{16}$

Summary of Questionnaire Results. Although the response to the questionnaire was so low as to preclude statistically conclusive data, the results obtained do reflect with some accuracy the character, habits, needs, and problems of well-trained productive professional anthropologists in the United States and abroad, especially in universities and museums. The high average number of man-hours spent in obtaining information, twelve per week, coupled with low usage of the few pertinent bibliographical aids available, indicates a need for improvement of these aids. It may also indicate a need for bibliographical instruction, perhaps in graduate school. As it is now, however, any bibliographical instruction given to anthropologists could not reasonably include, for example, the standard Wilson indexes. Specialized bibliographies and those personally compiled from footnotes are most used. The importance of keeping runs of periodicals intact was noted. The need for finding more efficient means of obtain-

\footnotetext{
${ }^{16}$ Alfred E. Dittert. Personal communication.
} 
ing foreign and unpublished materials was pointed out. The need for improved indexing and abstracting services is perhaps most acute. Services needed which could be provided by trained research assistants, librarians, or a central anthropological information agency include bibliography compilation, brief literature search, continuous scanning, translating, and abstracting. The problem of inadequate collections requires money, travel, and/or centralization. The problems of scattering of materials and inadequate cataloging can probably be solved best at present in specialized anthropology libraries. Facilities for obtaining foreign publications should improve, and, it is to be hoped, for unpublished materials also.

\section{Conclusions}

There appear to be at least four major contributions possible to partial solution of anthropology information problems. These are:

1. The first is a new kind of scholar, one who devotes himself to communication among the researchers and teachers in his field by the writing of synthesizing and evaluative bibliographical essays. Some anthropologists are doing this now on at least a part-time basis, but their efforts need to be integrated and their comprehensiveness increased. A broad background and a mind capable of synthesizing and seizing on less obvious relationships is needed for this valuable contribution.

2. The literature of anthropology as a whole needs a prompt cumulative comprehensive index-abstract service, including maps, films, and government publications. It should be adaptable to computerization.

3. For the individual anthropologist, the information specialist, and the library, a guide is needed to the literature, comparable to Parke's guide in mathematics, Whitford's in physics, and Pearl's in geology.
4. The museum or anthropology department library needs a practical handbook for organizing and running the library, using ideas from other types of special libraries where applicable, including automatic systems, and taking into account the unique characteristics of anthropological literature and its users, and discussing typical financial resources.

\section{Acknowledgements}

The author expresses appreciation to the persons who helped to make this research possible. Professor Bohdan Wynar of the University of Denver graduate school of librarianship gave encouragement and arranged for support. Professor Arnold M. Withers, chairman, and Professor Alan Olson of the University of Denver department of anthropology were consulted on the questionnaire.

Miss Margaret Currier, librarian of the Peabody Museum of Archaeology and Ethnology at Harvard University, devoted most of a day to helping the author, giving a guided tour of the library, and providing unpublished information and suggestions.

Dr. Alfred E. Dittert of the Laboratory of Anthropology in Santa Fe, generously gave the author hours of his time and outlined his efforts to date to start a Southwest Anthropology Bibliographical Center.

Professor Harry W. Basehart, chairman of the University of New Mexico department of anthropology and $\mathrm{Mr}$. Billy M. Kirkwood of the University of New Mexico computer center gave suggestions on handling of the questionnaire data.

Gratitude is particularly deserved by Professor Frank C. Hibben of the University of New Mexico, a fine teacher whose inspiration and encouragement are responsible for any merits in this paper. 